Article

\title{
Monitoring Climate Change in World Heritage Properties: Evaluating Landscape-Based Approach in the State of Conservation System
}

\author{
Paloma Guzman ${ }^{1, *(D)}$, Sandra Fatorić ${ }^{2}$ ad and Maya Ishizawa ${ }^{3}$ \\ 1 Norwegian Institute for Cultural Heritage Research (NIKU), 0155 Oslo, Norway \\ 2 Faculty of Architecture and the Built Environment, Delft University of Technology (TU Delft), 2628 BL Delft, \\ The Netherlands; s.fatoric@tudelft.nl \\ 3 Department of World Heritage Studies, University of Tsukuba, Tsukuba 305-8577, Japan; \\ maya@heritage.tsukuba.ac.jp \\ * Correspondence: paloma.guzman@niku.no
}

Received: 31 January 2020; Accepted: 4 March 2020; Published: 6 March 2020

\begin{abstract}
Climate change is increasingly being recognized as a threat to natural and cultural World Heritage $(\mathrm{WH})$ sites worldwide. Through its interaction with other stressors, climate change accelerates existing risks while also creating new obstacles. A more considerable focus is needed in both research and practice to explore proactive measures for combatting this issue (e.g., mitigation and actions prior to impacts occurring). World Heritage values in climate change decision-making processes is an important factor in this regard. This paper explores a discussion of climate change within the WH monitoring system. It offers an overview of practice based on the extent to which WH properties (natural, mixed and cultural) implement landscape-based approaches alongside the conservation and management of their outstanding universal value within the context of climate uncertainty and environmental change. Landscape approaches are gaining importance in the $\mathrm{WH}$ conservation system, where they aim to provide concepts and tools for managing heritage toward sustainable practices. This research analyses the state of conservation reports and provides an overview of practice across time, categories and geographical regions. Based on a theoretical approach, empirical analyses identify four landscape principles that are increasingly shaping the debate around climate change issues in $\mathrm{WH}$ properties. Although these are highly relevant to advancing much-needed collaboration among scientific disciplines and governance sectors, we argue that further understanding is required on the transformational process of heritage values, as well as on the nature-culture relationship, in order to underpin heritage as a source for local resilience and climate mitigation.
\end{abstract}

Keywords: climate change; world heritage: landscape approach; nature culture divide; integrative heritage management; monitoring; state of conservation reports

\section{Introduction}

In the coming decades, climate change risks to various socioeconomic and natural systems are expected to increase due to projected anthropogenic climate changes, demographic development, and land-use changes [1]. These changes are increasingly being recognised as threat multipliers for global natural and cultural heritage via their interaction with other stressors, thereby accelerating existing risks and creating new ones [1-3]. An initial report on climate change and World Heritage $(\mathrm{WH})$ properties (The term 'World Heritage properties' is used as indicated in the documents of the W System (Article 3 of the WH Convention). [4] stated that natural heritage may be jeopardised, whereas cultural properties (in addition to physical threats) will experience social and cultural impacts. In 2008, 
The United Nations Educational, Scientific and Cultural Organisation (UNESCO) released the 'Policy Document on the Impacts of Climate Change on World Heritage Properties'. The document highlights that 'communities [have changed] the way they live, work, worship and socialize in buildings, sites and landscapes, [some] migrating and abandoning their built heritage'; the document further suggests that 'climate change will be considered in all aspects of nominating, managing, monitoring and reporting on the status of these properties' [5]. Accordingly, it follows recognising that in addition to 'the overarching objective of safeguarding the outstanding universal values of WH properties', these properties must 'serve as laboratories where monitoring, mitigation and adaptation processes can be applied, tested and improved' [5]. However, recent studies [3,6,7] found that heritage conservation practice has primarily focused on reactive measures that are taken after climate change impacts occur; these impacts include damage or loss to heritage properties $[6,8,9]$.

The primary concern of $\mathrm{WH}$ decision makers and policymakers is maintaining the physical characteristics of heritage assets, through which their outstanding universal value (OUV) is conveyed [10,11]. This refers to the exceptional cultural or natural significance of WH properties [12]. Two aspects that warrant debate are embedded in the operationalisation of such requirements, which presents challenges to WH properties in terms of addressing climate change. The first is that conservation of WH values are often operationalised through static values and physical delimitations related to developing and managing properties [13-15]. The second consideration is that heritage values are categorised as natural and cultural, and their definition and monitoring are undertaken by different disciplinary entities $[16,17]$. Moreover, the fact that climate action related to WH has predominantly focused on risk and vulnerability assessments of their OUV [18] is linked to State party efforts that seek to avoid their properties being included in the list of WH in danger or even lose their designation as WH by being removed from the WH List [10]. The interest between State Parties to secure at any cost the positioning of their properties on the WH List, and the WH Centre and advisory bodies' efforts to promote transparent and ethical conservation practices, are increasingly clashing, rendering the WH Committee (WHCOM) a highly politicised arena [19]. This situation has not only damaged the credibility of the WHCOM but has also undermined the capacity of the WH monitoring system to provide fully transparent information about conservation processes [20].

The WH Centre and advisory bodies have made concrete efforts to advance systemic conceptualisations of heritage alongside sustainable conservation practices. Examples include recommendations and guidelines for the implementation of landscape approaches for managing the evolving character of properties' OUV [16,21], the integration of sustainable development perspectives to the processes of the World Heritage Convention (WHC) [22], as well as recent efforts to engage WH conservation in climate action $[3,23]$. Yet more consideration is needed in both research and practice to assess the efficiency of actions taken, and to explore or implement proactive measures that include $\mathrm{WH}$ values and aspects of climate change decision-making processes (e.g., designing and/or implementing efficient climate adaptation actions for $\mathrm{WH}$ properties) before impacts occur.

To address this gap, this paper recognises climate change as an adaptive challenge fundamentally linked to beliefs, values, and worldviews, as well as to power, politics, identity, and interests [24]. We consider a landscape-based approach to heritage conservation as a crucial strategy for overcoming the climate change challenge and biological and cultural diversity losses $[16,25,26]$. Using these concepts as a theoretical basis, this research explores how climate change is currently being discussed within the WH monitoring system. It offers a state of practice in relation to how WH properties (natural, mixed, and cultural) are implementing landscape-based approaches to the conservation and management of their OUV within the context of climate uncertainty and environmental change. To do this, we selected State of Conservation (SOC) reports to provide an overview of practice across time, categories, and geographical regions. SOC reports have largely been discussed in the literature as proof of the politicised conformation of the WH List $[20,27]$ and have been criticised for lacking reliable measures to ensure the effective conservation of $\mathrm{WH}$ properties over time [28]. These reports have also proven to be a key source for providing valuable information on trends of conservation practices and on factors 
affecting the conservation of properties [29]. The empirical analyses presented herein identifies four landscape principles based on theory that are increasingly shaping the debate around climate change issues regarding WH properties. Although these are highly relevant for advancing much-needed collaboration among scientific disciplines and governance sectors, we argue that deeper understanding is required about the transformational process of heritage values and of the nature-culture relationship.

\section{Landscape-Based Conservation and Monitoring Under Climate Change}

The theoretical paradigm that leads conservation practice within the WH framework is based on a dichotomy $[30,31]$, according to the naturalist ontology that influenced Western modern science, as it draws a distinction between humans and their natural environment [32,33]. This is exemplified by a distinction between natural and cultural heritage (defined in Articles 1 and 2 of the 1972 WH Convention) and the establishment of their respective advisory bodies. These include the International Union for Conservation of Nature (IUCN) for natural properties and the International Council of Monuments and Sites (ICOMOS) and the International Centre for the Study of the Preservation and Restoration of Cultural Property (ICCROM) for cultural properties. This division often causes clashes between the benefits of conserving natural values and those associated with cultural or social values, leading to competing priorities and conflicting interests in decision-making processes [34]. This is exacerbated to the extent that the conservation of socially constructed natural and cultural heritage values may become disassociated from their environmental settings and (climatic) processes $[24,25,35,36]$.

There is growing consensus in the scientific literature [37-39] regarding the value of a landscape-based approach to conservation, which can help to bridge the conceptual gap between nature and culture. From this integrative perspective, heritage places include people, their built environments and practices, local ecosystems and other ecological processes. Although landscape-based approaches originated in the field of nature conservation [40,41], over the past decade, the cultural sector has also made efforts for its implementation [42-44]. Furthermore, landscape-based conservation practices are recognised for their potential to connect policy and practice at multiple interacting spatial levels via the implementation of adaptive and integrated management systems [38]. Moreover, landscape-based approaches are being consolidated as integrated solutions for addressing sustainability challenges, and to contribute to the fulfilment of the Sustainable Development Goals (SGD) of Agenda 2030 [25,45]. In the following subsections, we present common principles of landscape approaches discussed in the fields of natural and cultural conservation. These serve as analytical dimensions of the landscape-based approach and help to organise the primary findings presented in section three.

\subsection{Landscape Scale and Governance}

Landscape scale is acknowledged as a field in which various entities, including humans, interact according to physical, biological, and social rules that determine their relationships [46-48]. Here, the upscaling of conservation actions (generally targeting individual species or monuments) to an entire landscape helps to understand how objects of conservation relate to one another and how they are part of economic, environmental, social and cultural change processes [26,49,50]. In this way, landscape scale represents the wider physical/spatial context in which heritage resources are located, encompassing all possible interactions within a system [51], including the urban context [29]. Hence, conservation that employs a landscape-based approach requires managing the co-benefits and trade-offs between a wide range of stakeholders. In this way, conservation becomes a process of negotiation, decision making and re-evaluation that is expected to be informed by science but shaped by human values and preferences [46,49].

A shared conservation vision requires a governance structure for the coordination of different levels of organisation, assessment and implementation of measures. Thus, landscape governance involves the institutions, organisations, and mechanisms by which communities currently govern their relationship with the natural environment and global bio-geophysical systems [52]. The processes of institutionalising climate change approaches that facilitate effective internal networks toward 
collaboration and the resolution of complex objectives are often generally poorly understood in heritage management that deals with climate change, but also in climate change governance [34,53,54].

\subsection{Evidence-Based Decision Making}

Evidence-based decision making is a critical aspect for the normative of landscape [46] and adaptive management [55]. Mapping, assessment, and monitoring tools are expected to facilitate research activities for the description of socioecological systems. Based on this evidence, stakeholders can improve their capacity to judge and respond to manage heritage resources in transforming environments [56-58]. Consequently, monitoring using a landscape-based approach can provide a basis for revising and improving management and conservation practices by considering the complexity of human institutions and behaviours in the context of environmentally driven change [46,59]. In practice, this requires transdisciplinary and collaborative approaches that are able to validate different data levels and sources $[29,60]$. To articulate the evidence needed and produced by different stakeholders into individual value systems, a shared conservation vision must be agreed on alongside the coordination of activities for implementing relevant measures [61,62]. This requires all stakeholders to consider the outcomes of a shared conservation vision from a more holistic perspective $[63,64]$.

\subsection{Adaptation Measures and the Resilience of Natural and Cultural Heritage}

According to the Intergovernmental Panel on Climate Change [1], the climate change adaptation of WH properties involves a decision-making process that seeks to reduce the vulnerability of WH areas to climate change and creating WH resilience to current and future climate change impacts [1]. Adaptation processes must consider the design and implementation of measures that can increase the resilience of landscape values and attributes $[46,50]$ while ensuring that cultural and/or natural significance is not adversely affected or lost [65]. Plieninger et al. [14] discuss how landscape governance has been dominated by a conservation approach in which designated areas with special features should not change. Consequently, some studies have highlighted the importance of developing and operationalising landscape-based management frameworks to enable the safeguarding of heritage values and attributes while at the same time allowing for change $[49,66]$. However, discussion on the thresholds of 'acceptable change' remains at an early stage, particularly on the topics of climate change mitigation and adaptation fields [65,67-69]; a larger focus has been on socioeconomic development and its impacts on $\mathrm{WH}$ properties [70-72].

To sustain landscape processes and associated heritage values long-term, landscape resilience (the capacity to absorb and recover from impacts) represents a vital aspect of climate change decisionmaking processes $[1,3]$. The key elements in building heritage resilience include social/adaptive learning and the monitoring of changes [73,74]. Monitoring is a valuable tool for generating data and knowledge that can serve as a basis for informed decision making in managing WH properties within a changing climate environment $[68,75]$.

\section{Methodology}

\subsection{Analysis Sources}

This study focused on using SOC reports and their qualitative data on WH management and conservation-related issues. The SOC reports, elaborated on a yearly basis, provided a brief analysis of the conservation threats to properties that both the WH Centre and advisory bodies considered as having high relevance for discussion by the WHCOM. These reports are requested when 'the values for which a property was inscribed on the WH List appear to be significantly threatened by either existing processes, or by potential processes with a high likelihood of taking place' [28] (e.g., climate change, development). Despite lacking quantitative information and analysis, SOC reports are the source of more objective discussions on WH issues such as the range of impacts on OUVs [12]. In their text format, reports include the viewpoints of the State party, advisory bodies, 
and the WH Centre in the form of concerns and recommendations that may differ from those of the national authorities or heritage managers [76]. Although SOC reports identify climate change and severe weather events among a list of 14 factors (https://whc.unesco.org/en/factors/) affecting the conservation of $\mathrm{WH}$ properties, the system does not systematically correlate extreme weather events (e.g., hurricane, drought) with climate change. Additionally, UNESCO's SOC database is not designed to provide systematic insights about the interactions between heritage management and the factors that both positively and negatively impact the conservation of WH properties. Nonetheless, it has proved valuable for the collation of information from numerous individual practices. Thus, SOC reports can be used to systematically assess patterns linked to the identification of threats to WH areas, management deficiencies, and conservation needs and developments [76]. For example, it has enabled the monitoring and quantification of the qualitative aspects of factors affecting the conservation of cultural and mixed heritage properties across time and geographical location [29].

\subsection{Data Collection}

In this study, we focused on 'climate change' as a key term. The SOC reports were downloaded from the UNESCO website and gathered in PDF format in order to conduct an advanced search in Acrobat Reader DC v.2020 using 'climate' + 'change' as keywords. Through directed content analysis, we sought to explore insights on the situational and management context in which climate change was noted in SOC monitoring exercises. The aim was to understand commonalities and differences between the challenges and/or opportunities discussed by conservation practice in all categories of WH properties when confronted by climate change as a global phenomenon of systemic complexity. We selected reports online from 2000 up to 2019.

\subsection{Data Analysis}

A coding system was applied to classify mentions of 'climate change' based on two pre-coding dimensions and two post-coding dimensions (Table 1). First, pre-coding identified mentions using the set of keywords 'climate change' and extracted all mentions found for analysis. The second pre-coding dimensions were SOC reports' general information, which was extracted and compiled in a Microsoft Excel spreadsheet in order to identify mentions according to the year of the SOC report, WH name, heritage category (i.e., natural, cultural, or mixed) and geographical location (country and region). The post-coding dimensions served to structure analysis involving advances in theory and practice. First, post-coding dimension three, context of references, identified the standard situational context in which mentions could be discussed, based on World Heritage Convention (WHC) protocols when elaborating on SOC reports. These included three viewpoints according to which debates on conservation issues revolved: (1) expression of concerns (C) by the WH Centre or advisory bodies on unresolved issues or possible negative outcomes of past and future measures; (2) recommendations (R) by both the WH Centre and advisory bodies to State Parties on prioritising actions; (3) implementations (I), which concerned the WHC's acknowledgement of efforts made by State Parties for dealing with a given threat or other conservation issues identified in previous WHC meetings. Viewpoints varied in order of appearance within reports. The second post-coding dimension, landscape-based conservation principles, comprised the operational definitions of landscape approaches identified through a taxonomic analysis of mentions. Four typologies were defined to formulate an initial framework for identifying landscape approaches related to climate change in WH conservation practices: (1) landscape scale, which refers to the upscaling of conservation activities in the wider context in which WH properties are located; (2) evidence of climate change impacts on OUV (lack or availability) to inform heritage management; (3) landscape governance, which includes the lack or existence of coherent planning and governance tools in collaboration with other sectors and actors (policies, management plans, and strategic actions); (4) adaptation measures addressing one of or the cumulative impacts of other identified factors that are exacerbated by climate change. 
Table 1. Coding dimensions and definitions.

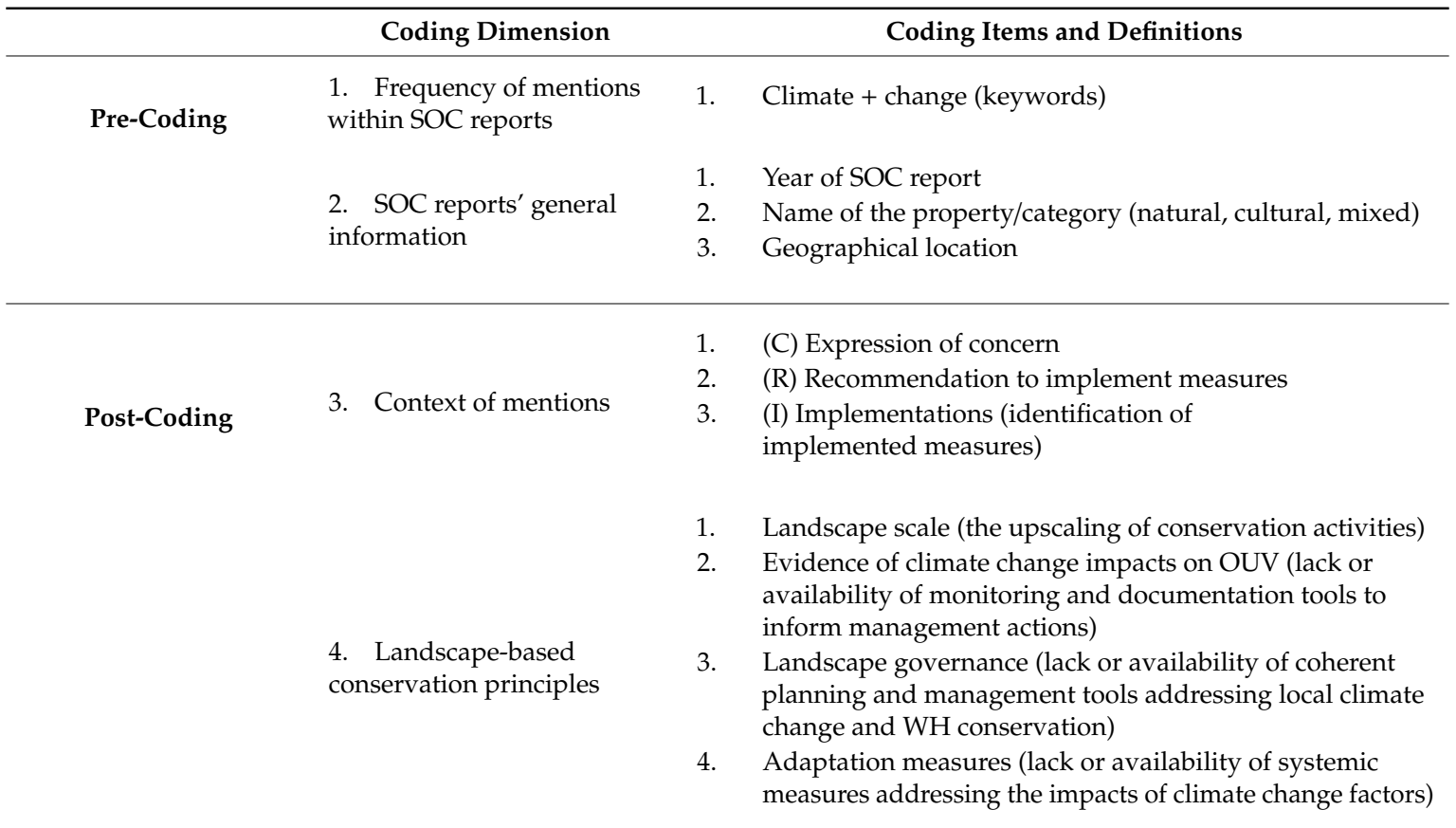

Collected qualitative data (mentions) were entered into an Excel spreadsheet and analysed using content analysis (Creswell, 2014). We calculated the frequency of each pre-coding and post-coding item, i.e., the number of times an item was coded across SOC reports. Next, relationships between pre and post-coding items were analysed based on their occurrence and following the hierarchical order of coding dimensions. The Excel COUNTIF function was used to count the number of extracted texts that met the criteria of coding dimensions. This allowed for interpretation of the meaning of mentions in the theoretical context of landscape conservation and the WH system. The key aspects of our analysis, which structured our results presented in the next section, were the following: (1) the complexity of discussion around climate change based on WH categories, regions (pre-coding dimensions one and two in Table 1) through the period 2000-2019; (2) the discussion of climate change drivers within the WH system (post-coding dimensions three and four in Table 1); (3) trends related to how WH conservation practice employed principles of landscape approaches to respond to climate change (relationships among all coding dimensions).

\section{Results}

\subsection{Pre-Coding Analysis: Frequency of Mentions to 'Climate Change' in State of Conservation Reports}

This section presents the results of the two pre-coding dimensions, frequency of mentions within SOC reports and SOC reports' general information (dimensions one and two in Table 1) and the correlation between their related items.

Although climate change risks to $\mathrm{WH}$ areas are acknowledged in the list of factors threatening properties (https://whc.unesco.org/en/factors/), our analysis showed that the term 'climate change' by itself was mentioned only 103 times within SOC reports in the period 2000-2019 (Figure 1). Mentions of climate change began appearing in 2000 and although these were not constant increased over time. The year 2017 had the highest number of mentions $(n=16)$, whereas 2002 and 2004 indicated no mentions. Mentions were observed referring to climate change as a general factor affecting the conservation of properties and rarely correlated to specific natural phenomena. The slow but increasing number of mentions across reports suggests that at the local level, climate change is still in an early identification stage within the WH system. 


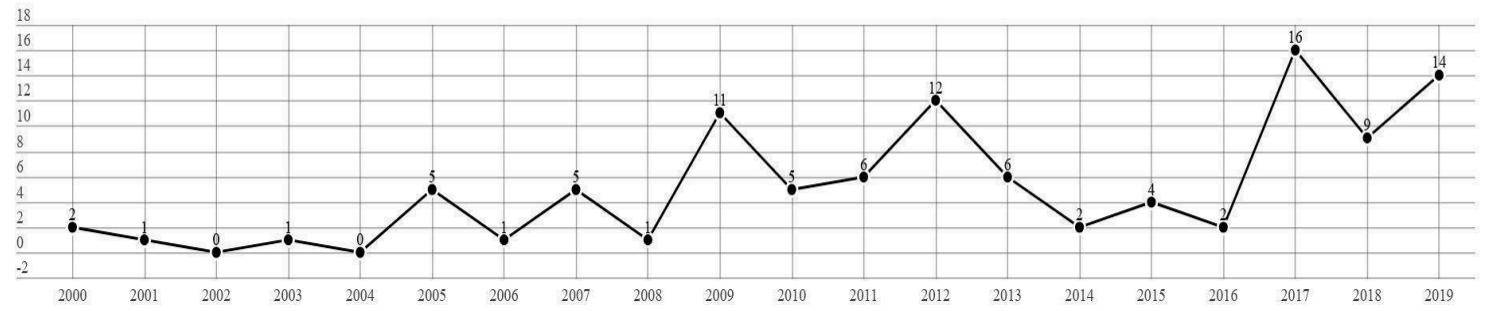

Figure 1. Timeline of total mentions $(\mathrm{n}=103)$ of 'climate change' between 2000 and 2019.

Currently, 1121 properties are included in the WH List. Among these, 77.5\% (869) are cultural properties, 19\% (213) are natural properties, and 3.5\% (39) are mixed properties. Only 574 of these properties have been discussed to date by the WHC and reported on in SOC reports. Similar to the distribution of categories on the WH List, cultural properties led the discussion on SOC reports on all negative impacts as it concerned the conservation of $\mathrm{WH}$ properties $(68.5 \%, \mathrm{n}=393)$, followed by natural properties at $27 \%(n=153)$ and $5 \%(n=28)$ for mixed properties. This study found that the 103 mentions to climate change were discussed as having an impact on 64 properties, corresponding to $6 \%$ of all $\mathrm{WH}$ properties on the list and $11 \%$ of properties discussed in SOC reports. However, the analysis found that natural properties took the lead in the debate on climate change impacts on OUV. Approximately $80 \%$ of the total mentions of climate change were made by natural properties, followed by cultural properties at $14 \%$. Mixed properties discussed climate change the least (6\%) (see Figure 2).

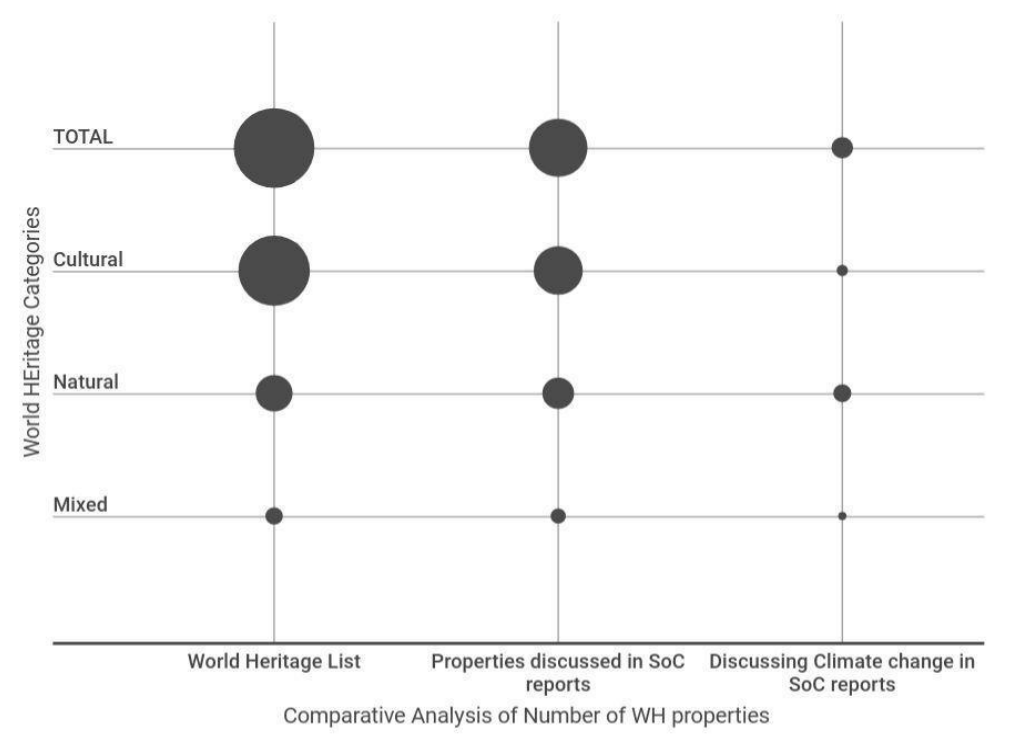

Figure 2. Comparison between total World Heritage $(\mathrm{WH})$ properties and properties in State of Conservation reports discussing climate change.

Figure 3 shows the distribution of WH properties discussing climate change, as well as the percentage of mentions of climate change issues per UNESCO geographical region. The analysis of the geographical distribution of mentions to climate change showed that Asia and the Pacific (APA) reported on climate change the most, followed by Europe (EUR), Africa (AFR), Latin America, and the Caribbean (LAC) and Arab States (ARA). However, the number of WH properties being affected by climate change showed a slight change in regional order, where APA and AFR accounted for a major number (17 properties), followed by EUR with 16 properties, LAC with 11 and, finally, ARA with only three properties. 

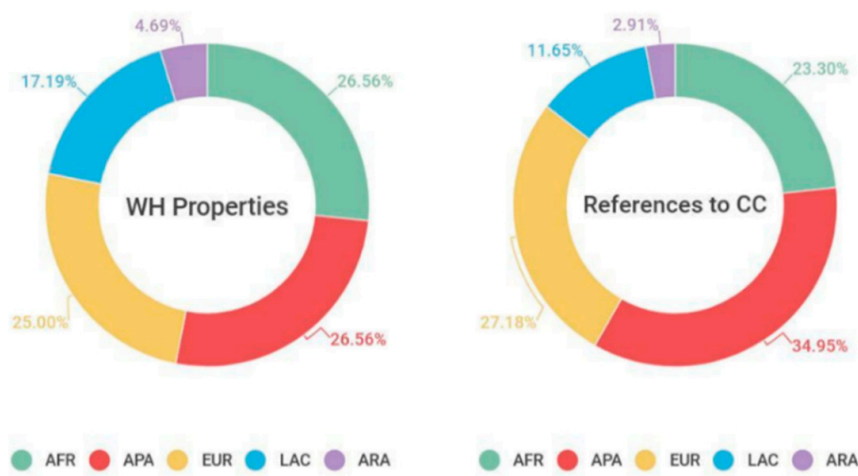

Figure 3. Distribution of WH properties discussing climate change (in \%) and total references to climate change (cc) per The United Nations Educational, Scientific and Cultural Organisation (UNESCO) geographical area.

\subsection{Post-Coding Analysis: The Context of Mentions and Landscape-Based Conservation Principles}

This section discusses the results of summative post-coding dimensions three and four in Table 1. Relationships between the relevant years of SOC reports (dimension one, item one in Table 1) were employed to present the evolution of post-coding items over time. Post-coding dimension three, contexts of mentions, identified expression of concerns as the predominant context in which climate change was discussed, with $47.6 \%$ of all mentions. The second type of mentions identified the implementation of actions and measures $(31 \%)$ presented by State Parties to the WH Centre. Rehabilitation activities and maintenance works, including concrete descriptions of actions such as the extension of boundaries and other adaptive interventions, were the most frequently mentioned measures. The final group corresponded to recommendations $(21.4 \%)$ made by the WH Centre and advisory bodies to State Parties during the WHCOM; these commonly focused on further steps for management and conservation improvements. An overview of the evolution of context of mentions is shown in Figure 4. Specific examples across WH categories are discussed and illustrated in the following section.

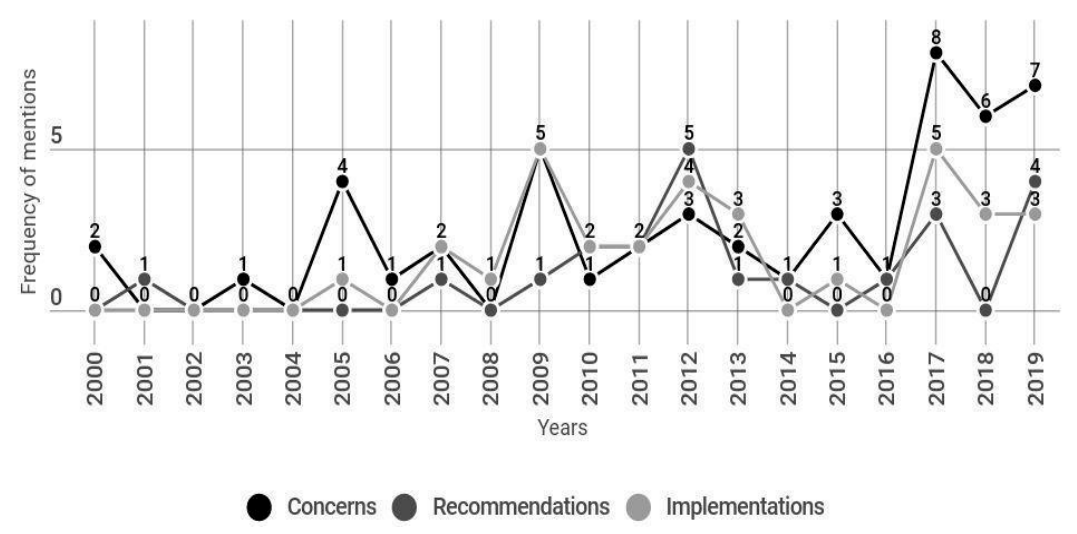

Figure 4. Mentions differentiated according to context (coding dimension 3).

Results from the post-coding analysis corresponding to dimension four in Table 1, landscape-based conservation principles, revealed the most pressing issue as a lack of evidence of climate change impacts on OUV (37.4\% of all mentions) (Figure 5). This principle highlights the role of monitoring and documentation tools for informing management actions and conservation measures. The second principle, adaptation measures, was observed in roughly one third of all SOC reports (36.7\%). This principle concerned the availability of systemic measures to address the impacts of climate change. Mentions discussing issues of landscape governance were in third place $(18 \%)$. This referred to the 
inclusion of heritage conservation at wider strategic and operational levels as a means for responding to climate change, particularly acknowledging policies, strategies, and the coordination of different management sectors. Finally, landscape scale was the least-discussed principle (8\%) and focused on the upscaling of conservation activities beyond WH property boundaries; the principle was also discussed in relation to socioeconomic context and other environmental or physical aspects pertaining to where properties were located.

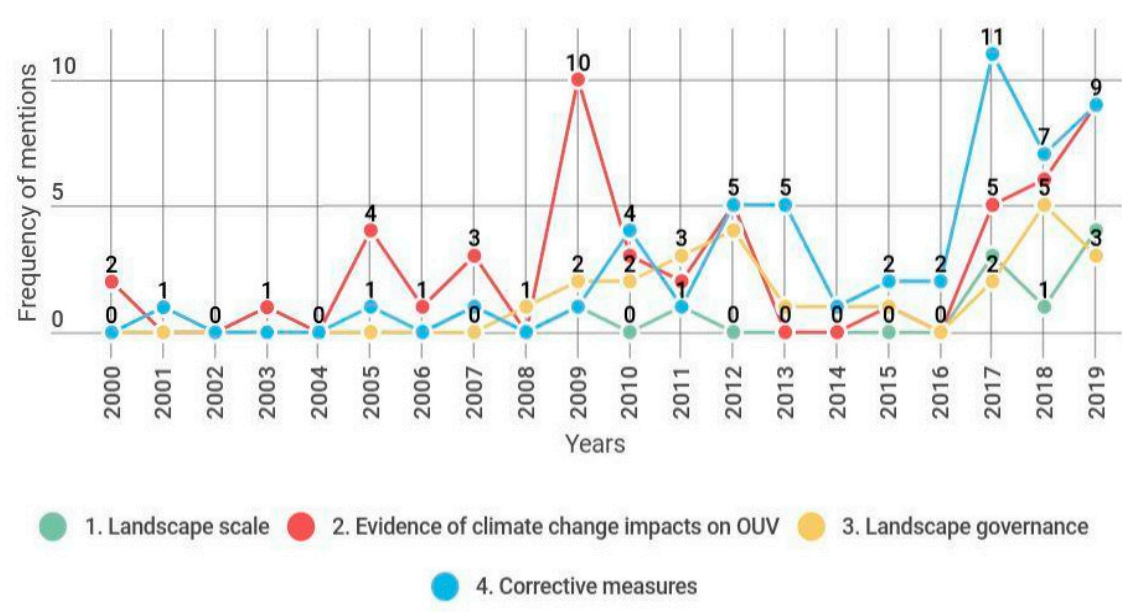

Figure 5. Mentions identified as landscape-based conservation principles (coding dimension 4).

The summative of post-coding dimensions that classify the types of mentions of climate change proved that these became more elaborated over time in taxonomic terms. This can be seen by the increase of concurrences of post-coding items over time. During the period 2009 to 2012, a peak in mentions of natural properties was observed to correlate with more than one item from landscape-based conservation principles and context of mentions. A second peak in correlations was observed from 2017 to 2019. In both periods, natural properties were found to be predominant; in the most recent period, however, cultural properties became more visible (see Figures 4 and 5). Latest discussions were more likely to include several items of post-coding dimensions three and four than earliest mentions. As such, these included the recognition of measures implemented by State Parties together with expressed concerns and provided recommendations. Additionally, each context of mentions could be linked to one or more landscape-based conservation principles. Yet, this does not necessarily mean that discussions on climate change are becoming more comprehensive regarding management practices. This is further explained in the next section. A general summary of findings is shown in Appendix A.

\subsection{Relationships between Post-Coding Dimensions}

In this section, we present the results of the relationship analysis between post-coding dimensions in hierarchical order. Here, post-coding dimension four, landscape-based principles, as well as related items aligned under items of post-coding dimension three, contexts of mentions.

Figure 6 indicates that the most frequent correlations between post-coding dimensions linked concerns (post-coding item 3.1) with adaptation measures (post-coding item 4.4). Examples of these mentions include common petitioning from the WHCOM to State Parties to reduce the impacts of previously identified threats (e.g., pollution, natural phenomena, natural resources depletion) that had been observed as exacerbated by climate change, and that may potentially increase a property's vulnerability. This situation suggests a lack of management and conservation strategies for reducing the vulnerability of WH properties to climate change, particularly to environmental risks. Following on closely, post-coding item 3.1, expression of concerns, correlated to post-coding item 4.2, evidence of climate change impacts. Considering that WH properties are requested to implement their own monitoring and documentation processes, related mentions highlighted a lack of adequate methods 
for documentation, data collection, and for assessing the impacts of climate change on properties' OUV as a means for informing and supporting the prioritisation of actions. It was observed that these mentions often lack a definition of the type of threat and how it is related to climate change; for example, an increase in the frequency and/or intensity of natural phenomena, or the transformation of environmental settings as stated in projections for particular local contexts, etc. Finally, concerns (item 3.1) showed the least correlation to post-coding items 4.3 and 4.1, landscape scale and landscape governance, respectively. These groups of mentions focused on understanding properties' components and conservation actions within a larger physical scope and included the involvement of a broader range of actors; for example, the consideration of WH properties at higher policy and management levels that targeted climate change. Examples of mentions found correlating dimension three, one, and dimension four per WH category are shown in the Table 2 item.

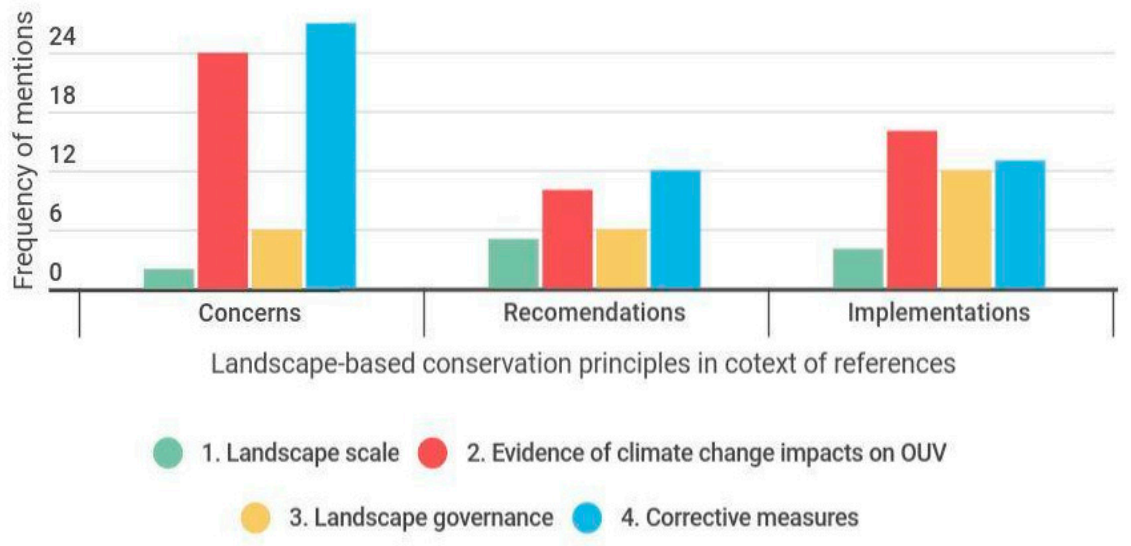

Figure 6. Illustrates the summative assessment of post-coding dimensions three and four.

The second group of correlations between post-coding dimensions, as shown in Figure 6, found an increasing recognition of implementation of measures primarily responding to the need for gathering evidence of the impacts of climate change on WH properties (post-coding items 3.3 and 4.2). More comprehensive monitoring programs and assessment studies are mentioned as requirements within the framework of studies and conservation programs that are primarily undertaken by an entity external to the national party and local management officials. Following on closely was the frequency of mentions for subgroups involving correlations between implementations of corrective measures (post-coding item 4.4) and landscape governance (post-coding item 4.3). These two categories are related because rehabilitation and maintenance activities are often strengthened at higher strategic and management levels; for example, for natural properties, such actions aim at maintaining OUV related to biodiversity. In cultural heritage, actions may include developing new protective infrastructures that can facilitate WH adaptation to climate change. These include considerations for heritage conservation in the form of strategic management and development plans applied at a broader territorial level in which heritage is embedded. The least frequent mention in this group (see Figure 6) correlated implementations with post-coding item 4.4, landscape scale. Related actions included the extension of WH properties' boundaries and the implementation of transboundary studies (e.g., the Great Himalayan National Park Conservation Area and the overall approach to the waterfront in the Historic Inner City of Paramaribo). Examples of this group are shown in Table 3.

The third group of correlations (Figure 6) corresponded to recommendations (post-coding item 3.2) made by the WHC to State Parties regarding climate change management and measures (post-coding item 4.4), followed by regular maintenance and adaptive management measures supported by enhanced monitoring tools and the involvement of wider governance levels (post-coding items 4.2 and 4.3). A final correlation represented acting in collaboration with other sectors for reducing threats and pressures that increased properties' vulnerability to climate change (post-coding item 4.1). Table 4 shows examples of this group of mentions. 
Table 2. Summary of main findings per WH category.

\begin{tabular}{|c|c|c|c|c|}
\hline $\begin{array}{l}\text { Mentions of Climate Change as Contexts of Mentions } \\
\text { (Dimensions One and Three) }\end{array}$ & \multicolumn{3}{|c|}{ Dim. 2: SOC Reports' General Information } & \multirow{2}{*}{$\begin{array}{c}\begin{array}{c}\text { Dim. 4: Landscape } \\
\text { Conservation Principles }\end{array} \\
\text { Item } 1-4\end{array}$} \\
\hline Item one: keywords in texts & Item 2 & 3 & 4 & \\
\hline $\begin{array}{l}\text { "[T]he current lack of effective site management for most } \\
\text { components, as well as identified threats. At present, [a] level of } \\
\text { protection and management is only available for the three large } \\
\text { forts. The other forts are mostly abandoned, with accelerated } \\
\text { degradation due to rising salts and humidity, lack of effective } \\
\text { management and the possibility of climate change impacts." }\end{array}$ & $\begin{array}{c}2019 \\
\text { Forts and castles, Volta, } \\
\text { Greater Accra, Central and } \\
\text { Western Regions }\end{array}$ & C & $\begin{array}{c}\text { Ghana, } \\
\text { AFR }\end{array}$ & $\begin{array}{l}\text { (1) Landscape scale } \\
\text { (2) Evidence of climate change } \\
\text { impacts } \\
\text { (4) Adaptation measures }\end{array}$ \\
\hline $\begin{array}{l}\text { "The Old City of Shibam, [constructed] of mud and located in a } \\
\text { flood prone area, remains at severe risk of major damage, unless } \\
\text { necessary preventive measures are taken. The effects of climate } \\
\text { change are exacerbating this problem. Therefore, the proposed } \\
\text { 'Shibam Oases Development Project' is essential for long-term } \\
\text { conservation. This project, which is part of a sustainable food } \\
\text { security program, involves preparation of a comprehensive } \\
\text { developmental plan for the conservation and use of Shibam oases, } \\
\text { which are considered as the buffer zone of the property." }\end{array}$ & $\begin{array}{c}2018 \\
\text { Old Walled City of Shibam }\end{array}$ & $\mathrm{C}$ & $\begin{array}{l}\text { Yemen } \\
\text { ARA }\end{array}$ & $\begin{array}{l}\text { (3) Landscape governance } \\
\text { (4) Adaptation measures }\end{array}$ \\
\hline $\begin{array}{l}\text { "According to the report, the site is subject to changes due to } \\
\text { socio-economic phenomena (schooling, infrastructure } \\
\text { development), human activities and environmental degradation } \\
\text { (climate change, demographic pressure). Some intangible cultural } \\
\text { practices are mutating due to contact with other imported values } \\
\text { (religions, cultural tourism)." }\end{array}$ & $\begin{array}{c}2013 \\
\text { Cliffs of Bandiagara (Land } \\
\text { of the Dogons) }\end{array}$ & $\mathrm{C} / \mathrm{N}$ & $\begin{array}{l}\text { Mali } \\
\text { AFR }\end{array}$ & (4) Adaptation measures \\
\hline $\begin{array}{l}\text { "[The] future integrity of the property [faces high] risk, taking } \\
\text { into account the possible prospect of offshore oil exploitation ... } \\
\text { uncertainty about the impact of invasive species, the already } \\
\text { existing threats for which progress on the corrective measures is } \\
\text { unclear and the globally increasing effects of climate change to } \\
\text { coral reef systems." }\end{array}$ & $\begin{array}{c}2012 \\
\text { Belize Barrier Reef } \\
\text { Reserve System }\end{array}$ & $\mathrm{N}$ & $\begin{array}{l}\text { Belize } \\
\text { LAC }\end{array}$ & (4) Adaptation measures \\
\hline
\end{tabular}


Table 3. Example of analysis implementations (item 3.2) and landscape conservation principles (dimension four)

\begin{tabular}{|c|c|c|c|c|}
\hline $\begin{array}{l}\text { Mentions of Climate Change as Implementations } \\
\text { (Dimensions One and Three) }\end{array}$ & \multicolumn{3}{|c|}{ Dim. 2: SOC Reports' General Information } & \multirow{2}{*}{$\begin{array}{c}\begin{array}{c}\text { Dim. 4: Landscape } \\
\text { Conservation Principles }\end{array} \\
\text { Items one to four }\end{array}$} \\
\hline Item one: keywords in texts & Items 2 & 3 & 4 & \\
\hline $\begin{array}{l}\text { "An India-Bangladesh Joint Working Group on Conservation of } \\
\text { the Sundarbans (JWG) has been created, which has led to an } \\
\text { agreement to conduct joint studies on the indicators to monitor } \\
\text { the health of the Sundarbans ecosystem and the impacts of } \\
\text { climate change and to protect the Bengal Tiger." }\end{array}$ & $\begin{array}{c}2019 \\
\text { Sundarbans }\end{array}$ & $\mathrm{N}$ & $\begin{array}{c}\text { Bangladesh } \\
\text { APA }\end{array}$ & $\begin{array}{l}\text { (1) Landscape scale } \\
\text { (2) Evidence of climate change } \\
\text { impacts } \\
\text { (4) Corrective measures }\end{array}$ \\
\hline $\begin{array}{l}\text { "Other issues are reported, such as the presence of clandestine } \\
\text { interventions in historic buildings, the potential impact of } \\
\text { wholesale trade and street markets and the need to improve risk } \\
\text { preparedness in the property in order to face El Niño and climate } \\
\text { change threats. All issues were taken into account in the } \\
\text { elaboration of the new Master Plan and are expected to be } \\
\text { addressed with its implementation." }\end{array}$ & $\begin{array}{c}2019 \\
\text { Historic Centre of Lima }\end{array}$ & $\mathrm{C}$ & $\begin{array}{l}\text { Peru } \\
\text { LAC }\end{array}$ & $\begin{array}{l}\text { (2) Evidence of climate change } \\
\text { impacts } \\
\text { (3) Landscape governance } \\
\text { (4) Corrective measures }\end{array}$ \\
\hline $\begin{array}{l}\text { "At Eridu, a landscape-based survey of the hinterland of the city } \\
\text { is being planned to research the impact of climate change on the } \\
\text { marshes, as is a survey of the city and a Conservation Plan; } \\
\text { funding is being sought for a five-year research, excavation and } \\
\text { enhancement project." }\end{array}$ & $\begin{array}{l}2018 \\
\text { The Ahwar of Southern } \\
\text { Iraq: Refuge of } \\
\text { Biodiversity and the Relict } \\
\text { Landscape of the } \\
\text { Mesopotamian Cities }\end{array}$ & $\mathrm{C} / \mathrm{N}$ & $\begin{array}{l}\text { Iraq } \\
\text { ARA }\end{array}$ & $\begin{array}{l}\text { (2) Evidence of climate change } \\
\text { impacts } \\
\text { (3) Landscape governance }\end{array}$ \\
\hline
\end{tabular}


Table 4. Example of analysis recommendations (item 3.3) and landscape conservation principles (dimension four).

\begin{tabular}{|c|c|c|c|c|}
\hline \multirow{2}{*}{$\begin{array}{c}\text { Mentions to Climate Change as Recommendations (Dimensions One } \\
\text { and Three) }\end{array}$} & \multicolumn{3}{|c|}{ Dim. 2: SOC Reports' General Information } & \multirow{2}{*}{$\begin{array}{c}\text { Dim. 4: Landscape } \\
\text { Conservation Principles } \\
\text { Items one to four }\end{array}$} \\
\hline & Item 2 & 3 & 4 & \\
\hline $\begin{array}{l}\text { "Several colonies continue to be observed outside the property and given } \\
\text { their susceptibility to other factors, including climate change, it is } \\
\text { recommended that the Committee encourage the State Party to develop a } \\
\text { proposal for an extension of the property in order to ensure that the } \\
\text { majority of the areas occupied by overwintering colonies are properly } \\
\text { protected and to increase the potential of the property to adapt to } \\
\text { changing climatic conditions and associated changes in the distribution } \\
\text { of overwintering colonies." }\end{array}$ & $\begin{array}{l}2019 \\
\text { Monarch Butterfly } \\
\text { Biosphere Reserve }\end{array}$ & $\mathrm{N}$ & $\begin{array}{c}\text { Mexico } \\
\text { LAC }\end{array}$ & $\begin{array}{l}\text { (1) Landscape scale } \\
\text { (2) Evidence of climate change } \\
\text { impacts } \\
\text { (4) Corrective measures }\end{array}$ \\
\hline $\begin{array}{l}\text { "With regard primarily to the issue of tourism pressure and the negative } \\
\text { impacts of climate change, the property remains subject to the } \\
\text { cumulative impact of ascertained and potential threats. Sufficient } \\
\text { improvement in the state of conservation and further progress with } \\
\text { mitigation are therefore [still needed] in order to maintain the } \\
\text { authenticity and integrity of the property and to protect its OUV to a } \\
\text { level that will prevent the property [from being] considered for } \\
\text { inscription on the List of World Heritage [Sites] in Danger." }\end{array}$ & $\begin{array}{c}2019 \\
\text { Venice and its lagoon }\end{array}$ & $\mathrm{C}$ & $\begin{array}{l}\text { Italy } \\
\text { EUR }\end{array}$ & $\begin{array}{l}\text { (2) Evidence of climate change } \\
\text { impacts } \\
\text { (4) Corrective measures }\end{array}$ \\
\hline $\begin{array}{l}\text { "The mission noted that the size of the area and the diversity of its } \\
\text { ecosystems contribute to its adaptive capacity to climate change. The } \\
\text { property would benefit from an active programme for monitoring the } \\
\text { impacts of climate change, including ... carrying out a vulnerability } \\
\text { assessment for both natural and cultural (archaeological) resources and } \\
\text { to prepare an adaptation strategy on that basis. This could be integrated } \\
\text { within the recommended strategy and action plan for reducing risks to } \\
\text { the World Heritage property." }\end{array}$ & $\begin{array}{c}2007 \\
\text { Tasmanian wilderness }\end{array}$ & $\mathrm{C} / \mathrm{N}$ & Australia APA & $\begin{array}{l}\text { (1) Landscape scale } \\
\text { (2) Evidence of climate change } \\
\text { impacts } \\
\text { (3) Landscape governance }\end{array}$ \\
\hline
\end{tabular}




\section{Discussion and Conclusions}

This study provided an overview of how climate change is discussed within the WH monitoring system (SOC reports). The reliability of this monitoring tool is often challenged by politicised clashes between State Parties, the WH Centre, and advisory bodies. Despite such limitations, this research revealed that progress has been made in terms of recognising climate change as a threat to WH properties. However, addressing this issue has not yet been sufficiently integrated within the monitoring system. Only $64(6 \%)$ of all WH properties mentioned climate change in SOC reports. Among WH categories, natural heritage leads the discussion on climate change. This is explained by the fact that their OUV is based on environmental characteristics that are directly affected by climate change $[77,78]$. Although cultural heritage properties have gained visibility in recent years, the number of both cultural and mixed properties are unlikely to reflect the reality of current climate challenges worldwide. This is particularly true when considering the increasing number of literature on climate risks and vulnerability assessments [18].

In this study, we identified four principles of landscape-based approaches used as a response to climate change challenges for the conservation of natural, cultural and mixed properties mentioned in SOC reports. These principles were observed predominantly as concerns expressed by the WHCOM regarding the need for adaptive measures and for gathering evidence that is more consistent regarding the impacts of climatic factors on the OUV of properties. Additionally, monitoring and evidence-based management are increasingly being requested. This suggests that monitoring tools requested by the Operational Guidelines for the Implementation of the WHC (and as part of the process for a property to be nominated with WH status) are likely insufficient for assessing the complexity of climate change in relation to $\mathrm{WH}$ conservation.

Conservation using a landscape approach provides considerable room for action regarding collaborative strategies among governance and managerial sectors at the local level. Our results showed that both the upscaling of conservation activities in its wider context, as well as partnerships among different sectoral and governance sectors, can benefit from additional exploration in the context of climate change solutions. Our analysis also identified that a clarification is required regarding two aspects of what is being monitored and reported as 'climate change' in SOC reports. The first aspect refers to the identification of threats resulting from climate change, e.g., the increase in frequency and/or intensity of given natural phenomena. The second aspect refers to the transformation of environmental settings as part of the earth's natural processes related to climate change. Differentiation in the reporting and monitoring of such situational aspects raises two very different challenges for the conservation discipline. Increasing natural phenomena and their related risks challenge local managerial capacities and calls for adaptation strategies and risk preparedness. Furthermore, the transformation of the planet's physical environment can (and should) lead to deeper questioning of the paradigm behind the conservation discipline. According to Solli et al. [79], 'The more fundamental (almost existential) question is what will climate change do to the concept of heritage and our way of expressing scientific narratives about the past?'

We conclude that landscape approaches require additional study not only for the management of WH properties but also for the expansion of heritage conceptualisations. Climate change makes evident the need for deeper connections between cultural and natural values. Thus, heritage understandings should be expanded to include local, regional and/or State significance, and into the relationships between nature and culture. In this sense, developing a common understanding of what constitutes anthropogenic climate change and its associated impacts, including how these can be reduced through feasible climate adaptation actions for both natural and cultural properties, may serve as a crucial first step in improving the monitoring of WH properties. As highlighted in existing research [49,80], a new or revised operationalisation of the limits of acceptable change, without losing heritage values, is crucial for the climate adaptation of WH properties. However, this responsibility should not fall solely on the UNESCO WH system. Rather, it should be undertaken primarily by State Parties as part of their own agendas on mitigation and adaptation to climate change. For policymakers, the exploration 
and implementation of landscape-based management approaches can advance the adaptation and strengthening of WH multi-scale governance systems. This can foster the operationalisation of local sustainable goals that can integrate heritage values, while also enhancing good governance practices.

Furthermore, adapting comparative methods such as those used by qualitative datasets for policy analysis [81] can help to uncover useful pathways for UNESCO agendas. For example, using the concept of saliency can retrospectively reconstruct policy agendas, compare agendas over time, enable scholars to reconstruct relative attention to all issues on an agenda, and benefit the monitoring system with a more transparent and systematic analysis for all WH properties. This will allow for embedding WH contexts within larger environmental and political processes of climate adaptation and mitigation.

In the meantime, UNESCO is presently updating its climate change policy for WH properties (see https://whc.unesco.org/en/climatechange/). The updated policy is expected to promote preventive and proactive measures for implementation by State Parties in order to strengthen the resilience of cultural and natural WH properties. The landscape principles discussed in this paper can serve as a basis for addressing the gaps in practice and knowledge related to the climate change management of WH properties and address related impacts through actions for adaptation and mitigation.

Author Contributions: Conceptualization, P.G.; revisions and refinement of methodology, S.F. and M.I.; validation, S.F. and M.I.; formal analysis, P.G.; resources, all authors; data curation, P.G.; writing-original draft preparation, P.G.; writing - review and editing, all authors; visualization, P.G.; project administration, P.G.; funding acquisition, NIKU. All authors have read and agreed to the published version of the manuscript.

Funding: This work was supported by the Research Council of Norway [160010/F40].

Conflicts of Interest: The authors declare no conflict of interest. The funders had no role in the design of the study; in the collection, analyses, or interpretation of data; in the writing of the manuscript, or in the decision to publish the results.

\section{Appendix A}

Table A1. Summary of the total number of mentions per WH category (does not include the total number of WH properties).

\begin{tabular}{|c|c|c|c|c|c|}
\hline \multirow{2}{*}{ Coding Dimension } & \multirow{2}{*}{ Coding Items } & \multirow{2}{*}{$\begin{array}{c}\text { Total } \\
\text { Mentions }\end{array}$} & \multicolumn{3}{|c|}{ WH Categories (Dimension Two, Item Three) } \\
\hline & & & Natural & Cultural & Mixed \\
\hline 1. Freq. of mentions & $\begin{array}{l}\text { 1. No. of times climate change is } \\
\text { mentioned (mentions) }\end{array}$ & 103 & 83 & 14 & 6 \\
\hline \multirow{3}{*}{$\begin{array}{l}\text { 2. SOC reports' general } \\
\text { information }\end{array}$} & APA & 36 & 32 & 3 & 1 \\
\hline & EUR & 28 & 24 & 3 & 1 \\
\hline & ARA & 3 & 1 & 1 & 1 \\
\hline \multirow{3}{*}{ 3. Context of mentions } & 1. Concerns $(\mathrm{C})$ & 49 & 38 & 8 & 3 \\
\hline & 2. Recommendations (R) & 22 & 20 & 1 & 1 \\
\hline & 3. Implementations (I) & 32 & 25 & 5 & 2 \\
\hline $\begin{array}{l}\text { 4. Landscape-based } \\
\text { conservation principles }\end{array}$ & 1. Landscape scale & 11 & 8 & 2 & 1 \\
\hline
\end{tabular}

\section{References}

1. IPCC. Fifth Assessment Report: Climate Change; IPCC: Geneva, Switzerland, 2014.

2. Heathcote, J.; Fluck, H.; Wiggins, M. Predicting and Adapting to Climate Change: Challenges for the Historic Environment. Hist. Environ. Policy Pract. 2017, 8, 89-100. [CrossRef]

3. ICOMOS. The Future of Our Pasts: Engaging Cultural Heritage in Climate Action; ICOMOS: Paris, France, 2019. 
4. UNESCO. Climate Change and World Heritage: Report on predicting and managing the impacts of climate change on World Heritage and strategy to assist State Parties to implement appropriate management responses. World Herit. Rep. 2007, 22, 1-55.

5. UNESCO. Policy Document on the Impacts of Climate Change on World Heritage Properties; UNESCO: Paris, France, 2008.

6. Harkin, K.; Davies, D.; Hyslop, M.; Fluck, E.; Wiggins, H.; Merritt, M.; Barker, O.; Deery, L.; McNeary, M.; Westley, R. Impacts of climate change on cultural heritage. MCCIP Sci. Rev. 2020, 16, 24-39.

7. Fatorić, S.; Seekamp, E. Evaluating a decision analytic approach to climate change adaptation of cultural resources along the Atlantic Coast of the United States. Land Use Policy 2017, 68, 254-263. [CrossRef]

8. Heron, S.F.; Eakin, C.M.; Douvere, F.; Anderson, K.; Day, J.C.; Geiger, E.; Hoegh-Guldberg, O.; van Hooidonk, R.; Hughes, T.; Obura, D.O. Impacts of Climate Change on World Heritage Coral Reefs: A First Global Scientific Assessment; UNESCO: Paris, France, 2017; pp. 1-14.

9. Sesana, E.; Gagnon, A.S.; Bonazza, A.; Hughes, J.J. An integrated approach for assessing the vulnerability of World Heritage Sites to climate change impacts. J. Cult. Herit. 2020, 41, 211-224. [CrossRef]

10. Perry, J. Climate Change Adaptation in Natural World Heritage Sites: A Triage Approach. Climate 2019, 7, 105. [CrossRef]

11. Hall, C.M.; Baird, T.; James, M.; Ram, Y. Climate change and cultural heritage: Conservation and heritage tourism in the anthropocene. J. Herit. Tour. 2016, 11, 10-24. [CrossRef]

12. UNESCO. Operational Guidelines for the Implementation of the World Heritage Convention; UNESCO: Paris, France, 2015.

13. Pendlebury, J.; Short, M.; While, A. Urban World Heritage Sites and the problem of authenticity. Cities 2009, 26, 349-358. [CrossRef]

14. Plieninger, T.; Kizos, T.; Bieling, C.; Le Dû-Blayo, L.; Budniok, M.A.; Bürgi, M.; Kuemmerle, T.; Crumley, C.L.; Girod, G.; Howard, P. Exploring ecosystem-change and society through a landscape lens: Recent progress in european landscape research. Ecol. Soc. 2015, 20, 1-10. [CrossRef]

15. Zamarbide Urdaniz, A.V. Regional Heritage Dimensions vs. Management Boundaries. Int. Rev. Spat. Plan. Sustain. Dev. 2018, 6, 64-81.

16. Badman, T.; Kormos, C.F.; Jaeger, T.; Bertzky, B.; van Merm, R.; Osipova, E.; Larsen, P.B. World Heritage, Wilderness and Large Landscapes and Seascapes; IUCN International Union for Conservation of Nature: Gland, Suisse, 2017.

17. ICOMOS. Guidance on Heritage Impact Assessments for Cultural World Heritage Properties; ICOMOS: Paris, France, 2011.

18. Fatorić, S.; Seekamp, E. Are cultural heritage and resources threatened by climate change? A systematic literature review. Clim. Chang. 2017, 142, 227-254. [CrossRef]

19. Brown, N.E.; Liuzza, C.; Meskell, L. The Politics of Peril: UNESCO's List of World Heritage in Danger. J. Field Archaeol. 2019, 44, 287-303. [CrossRef]

20. Meskell, L. States of conservation: Protection, politics, and pacting within UNESCO's world heritage committee. Anthropol. Q. 2014, 87, 217-243. [CrossRef]

21. UNESCO. UNESCO Recommendation on the Historic Urban Landscape; UNESCO: Paris, France, 2011.

22. UNESCO. Policy Document for the Integration of a Sustainable Development Perspective into the Processes of the World Heritage Convention; UNESCO: Paris, France, 2015.

23. Osipova, E.; Wilson, L.; Blaney, R.; Shi, Y.; Fancourt, M.; Strubel, M.; Verschuuren, B. The Benefits of Natural World Heritage: Identifying and Assessing Ecosystem Services and Benefits Provided by the World's Most Iconic Natural Places; IUCN: Gland, Switzerland, 2014.

24. Adger, W.N.; Barnett, J.; Brown, K.; Marshall, N.; O’Brien, K. Cultural dimensions of climate change impacts and adaptation. Nat. Clim. Chang. 2013, 3, 112-117. [CrossRef]

25. Reed, J.; Van Vianen, J.; Deakin, E.L.; Barlow, J.; Sunderland, T. Integrated landscape approaches to managing social and environmental issues in the tropics: Learning from the past to guide the future. Glob. Chang. Biol. 2016, 22, 2540-2554. [CrossRef]

26. Bandarin, F.; van Oers, R. The Historic Urban Landscape: Managing Heritage in an Urban Century; Wiley-Blackwell: Oxford, UK, 2012; Volume 3.

27. Meskell, L.; Liuzza, C.; Bertacchini, E.; Saccone, D. Multilateralism and UNESCO World Heritage: Decision-making, States Parties and political processes. Int. J. Herit. Stud. 2015, 21, 423-440. [CrossRef] 
28. Turner, M.; Roders, A.P.; Patry, M. Revealing the Level of Tension Between Cultural Heritage and Development in World Heritage Cities. Probl. Sustain. Dev. 2012, 7, 23-31.

29. Guzman, P.; Roders, A.P.; Colenbrander, B. Impacts of Common Urban Development Factors on Cultural Conservation in World Heritage Cities: An Indicators-Based Analysis. Sustainability 2018, 10, 853. [CrossRef]

30. Ishizawa, M. Cultural Landscapes Link to Nature: Learning from Satoyama and Satoumi. Built Herit. 2018, 4, 7-19.

31. Linnell, J.D.C.; Kaczensky, P.; Wotschikowsky, U.; Lescureux, N.; Boitani, L. Framing the relationship between people and nature in the context of European conservation. Conserv. Biol. 2015, 29, 978-985. [CrossRef]

32. Descola, P.; Lloyd, J.; Sahlins, M. Beyond Nature and Culture; University of Chicago Press: Chicago, IL, USA, 2013.

33. Descola, P.; Pálsson, G. Nature and Society: Anthropological Perspectives; Taylor \& Francis: Abingdon-on-Thames, UK, 1996.

34. Fatorić, S.; Seekamp, E. Securing the Future of Cultural Heritage by Identifying Barriers to and Strategizing Solutions for Preservation under Changing Climate Conditions. Sustainability 2017, 9, 2143. [CrossRef]

35. Simensen, T.; Halvorsen, R.; Erikstad, L. Methods for landscape characterisation and mapping: A systematic review. Land Use Policy 2018, 75, 557-569. [CrossRef]

36. Smith, L. Uses of Heritage; Routledge: Abingdon-on-Thames, UK, 2006.

37. Pfund, J.L. Landscape-scale research for conservation and development in the tropics: Fighting persisting challenges. Curr. Opin. Environ. Sustain. 2010, 2, 117-126. [CrossRef]

38. Brunetta, G.; Voghera, A. Evaluating landscape for shared values: Tools, principles, and methods. Landsc. Res. 2008, 33, 71-87. [CrossRef]

39. Wu, J. Landscape sustainability science: Ecosystem services and human well-being in changing landscapes. Landsc. Ecol. 2013, 28, 999-1023. [CrossRef]

40. Gustafson, E.J. Quantifying landscape spatial pattern: What is the state of the art? Ecosystems 1998, 1, $143-156$. [CrossRef]

41. Tscharntke, T.; Tylianakis, J.M.; Rand, T.A.; Didham, R.K.; Fahrig, L.; Batáry, P.; Bengtaaon, J.; Clough, Y.; Crist, T.O.; Ewers, R.M. Landscape moderation of biodiversity patterns and processes-Eight hypotheses. Biol. Rev. 2012, 87, 661-685. [CrossRef]

42. Bandarin, F.; van Oers, R. (Eds.) Reconnecting the City: The Historic Urban Landscape Approach and the Future of Urban Heritage; Wiley-Blackwell: Oxford, UK, 2014.

43. Roders, A.P.; Bandarin, F. (Eds.) Reshaping Urban Conservation: The Historic Urban Landscape Approach in Action; Springer: Singapore, 2019.

44. Veldpaus, L. Historic Urban Landscapes, Framing the Integration of Urban and Heritage Planning in Multilevel Governance; Eindhoven University of Technology: Eindhoven, The Netherlands, 2015.

45. Van Oers, R.; Roders, A.P. Aligning agendas for sustainable development in the post 2015 world. J. Cult. Herit. Manag. Sustain. Dev. 2014, 4, 122-132. [CrossRef]

46. Sayer, J.; Sunderland, T.; Ghazoul, J.; Pfund, J.L.; Sheil, D.; Meijaard, E.; Van Oosten, C. Ten principles for a landscape approach to reconciling agriculture, conservation, and other competing land uses. Proc. Natl. Acad. Sci. USA 2013, 110, 8349-8356. [CrossRef]

47. Aplin, G. World heritage cultural landscapes. Int. J. Herit. Stud. 2007, 13, 427-446. [CrossRef]

48. Olwig, K.R.; Dalglish, C.; Fairclough, G.; Herring, P. Introduction to a special issue: The future of landscape characterisation, and the future character of landscape-Between space, time, history, place and nature. Landsc. Res. 2016, 41, 169-174. [CrossRef]

49. Veldpaus, L.; Roders, A.P.; Colenbrander, B.J.F. Urban Heritage: Putting the Past into the Future. Hist. Environ. 2013, 4, 18-33. [CrossRef]

50. Verburg, P.H.; van Asselen, S.; van der Zanden, E.H.; Stehfest, E. The representation of landscapes in global scale assessments of environmental change. Landsc. Ecol. 2013, 28, 1067-1080. [CrossRef]

51. Tress, B.; Tress, G.; Décamps, H.; D’Hauteserre, A.M. Bridging human and natural sciences in landscape research. Landsc. Urban Plan. 2001, 57, 137-141. [CrossRef]

52. Taylor, K.; Lennon, J. Cultural landscapes: A bridge between culture and nature? Int. J. Herit. Stud. 2011, 17, 537-554. [CrossRef]

53. Aylett, A. Institutionalizing the urban governance of climate change adaptation: Results of an international survey. Urban Clim. 2015, 14, 4-16. [CrossRef] 
54. Phillips, H. The capacity to adapt to climate change at heritage sites-The development of a conceptual framework. Environ. Sci. Policy 2015, 47, 118-125. [CrossRef]

55. Boyle, M.; Kay, J.; Pond, B. Monitoring in support of policy: An adaptive ecosystem approach. Encycl. Glob. Environ. Chang. 2001, 4, 116-137.

56. Hou, W.; Walz, U. Enhanced analysis of landscape structure: Inclusion of transition zones and small-scale landscape elements. Ecol. Indic. 2013, 31, 15-24. [CrossRef]

57. Volpiano, M. Indicators for the Assessment of Historic Landscape Features. In Landscape Indicators; Cassatella, C., Peano, A., Eds.; Springer: Dordrecht, The Netherlands, 2011; pp. 77-104.

58. Tengberg, A.; Fredholm, S.; Eliasson, I.; Knez, I.; Saltzman, K.; Wetterberg, O. Cultural ecosystem services provided by landscapes: Assessment of heritage values and identity. Ecosyst. Serv. 2012, 2, 14-26. [CrossRef]

59. Cassatella, C.; Peano, A. Indicators for the Assessment of Historic Landscape Features. In Landscape Indicators; Cassatella, C., Peano, A., Eds.; Springer: Dordrecht, The Netherlands, 2011; Volume 53, pp. 1-30.

60. Stem, C.; Margoluis, R.; Salafsky, N.; Brown, M. Monitoring and evaluation in conservation: A review of trends and approaches. Conserv. Biol. 2005, 19, 295-309. [CrossRef]

61. Bond, A.; Langstaff, L.; Baxter, R.; Kofoed, H.-G.W.J.; Lisitzin, K.; Lundström, S. Dealing with the cultural heritage aspect of environmental impact assessment in Europe. Impact Assess. Proj. Apprais. 2004, 22, 37-45. [CrossRef]

62. Rössler, M. World Heritage cultural landscapes: A UNESCO flagship programme 1992-2006. Landsc. Res. 2006, 31, 333-353. [CrossRef]

63. Ahern, J. Urban landscape sustainability and resilience: The promise and challenges of integrating ecology with urban planning and design. Landsc. Ecol. 2013, 28, 1203-1212. [CrossRef]

64. Sunderland, T.C.H.; Ehringhaus, C.; Campbell, B.M. Conservation and development in tropical forest landscapes: A time to face the trade-offs? Environ. Conserv. 2007, 34, 276-279. [CrossRef]

65. Fatorić, S.; Seekamp, E. A measurement framework to increase transparency in historic preservation decision-making under changing climate conditions. J. Cult. Herit. 2018, 30, 168-179. [CrossRef]

66. Reed, J.; van Vianen, J.; Barlow, J.; Sunderland, T. Have integrated landscape approaches reconciled societal and environmental issues in the tropics? Land Use Policy 2017, 63, 481-492. [CrossRef]

67. Xiao, X.; Seekamp, E.; van der Burg, M.P.; Eaton, M.; Fatorić, S.; McCreary, A. Optimizing historic preservation under climate change: Decision support for cultural resource adaptation planning in national parks. Land Use Policy 2019, 83, 379-389. [CrossRef]

68. Haugen, A.; Bertolin, C.; Leijonhufvud, G.; Olstad, T.; Broström, T. A Methodology for Long-Term Monitoring of Climate Change Impacts on Historic Buildings. Geosciences 2018, 8, 370. [CrossRef]

69. Heilen, M.; Altschul, J.H.; Lüth, F. Modelling Resource Values and Climate Change Impacts to Set Preservation and Research Priorities. Conserv. Manag. Archaeol. Sites 2018, 20, 261-284. [CrossRef]

70. Fouseki, K.; Nicolau, M. Urban Heritage Dynamics in 'Heritage-Led Regeneration': Towards a Sustainable Lifestyles Approach. Hist. Environ. Policy Pract. 2018, 9, 229-248. [CrossRef]

71. Guzmán, P.C.; Roders, A.R.P.; Colenbrander, B.J.F. Measuring links between cultural heritage management and sustainable urban development: An overview of global monitoring tools. Cities 2017, 60, 192-201. [CrossRef]

72. Harvey, D.; Perry, J. (Eds.) The Future of Heritage as Climates Change; Routledge: London, UK, 2015.

73. Garcia, B.M. Resilient cultural heritage: From global to national levels-The case of Bhutan. Disaster Prev. Manag. An. Int. J. 2019, 29, 36-46. [CrossRef]

74. O’Brien, G.; O'Keefe, P.; Jayawickrama, J.; Jigyasu, R. Developing a model for building resilience to climate risks for cultural heritage. J. Cult. Herit. Manag. Sustain. Dev. 2015, 5, 99-114. [CrossRef]

75. Daly, C. The design of a legacy indicator tool for measuring climate change related impacts on built heritage. Herit. Sci. 2016, 4, 19. [CrossRef]

76. Young, C. Understanding management in a world heritage context: Key current issues in Europe. Hist. Environ. Policy Pract. 2016, 7, 189-201. [CrossRef]

77. Perry, J. World Heritage hot spots: A global model identifies the 16 natural heritage properties on the World Heritage List most at risk from climate change. Int. J. Herit. Stud. 2011, 17, 426-441. [CrossRef]

78. Perry, J. Climate change adaptation in the world's best places: A wicked problem in need of immediate attention. Landsc. Urban Plan. 2015, 133, 1-11. [CrossRef] 
79. Solli, B.; Burström, M.; Domanska, E.; Edgeworth, M.; Gonz'alez-Ruibal, A.; Holtorf, C.; Lucas, G.; Oestigaard, T.; Smith, L. Some Reflections on Heritage and Archaeology in the Anthropocene. Nor. Archaeol. Rev. 2011, 44, 40-88. [CrossRef]

80. Jokilehto, J. Considerations on authenticity and integrity in World Heritage context. City Time 2006, 2, 1-16.

81. Alexandrova, P.; Carammia, M.; Princen, S.; Timmermans, A. Measuring the European Council agenda: Introducing a new approach and dataset. Eur. Union Polit. 2013, 15, 152-167. [CrossRef]

(c) ( 